\title{
Estimating the water requirements of high yielding and young apple orchards in the winter rainfall areas of South Africa using a dual source evapotranspiration model
}

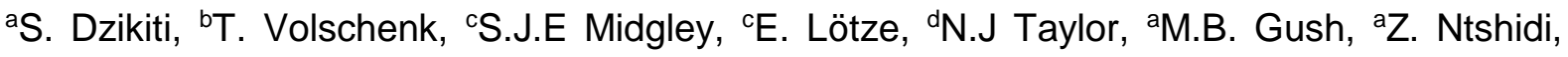
' S.F Zirebwa, ${ }^{\mathrm{d}} \mathrm{Q}$ Doko, ${ }^{\mathrm{C} M}$. Schmeisser, ${ }^{\mathrm{f}} \mathrm{C}$ Jarmain, ${ }^{\mathrm{ce} W}$.J Steyn, ${ }^{\text {aHH Pienaar }}$

aCouncil for Scientific and Industrial Research (CSIR), Natural Resources and Environment, Stellenbosch, South Africa; ${ }^{b} A R C$ Infruitec-Nietvoorbij, Soil and Water Science Programme, Stellenbosch, South Africa; cUniversity of Stellenbosch, Department of Horticultural Science, South Africa; dDepartment of Plant and Soil Sciences, University of Pretoria; e HORTGRO Science, South

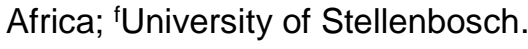

Corresponding author: Sebinasi Dzikiti

Natural Resources and the Environment, Council for Scientific and Industrial Research, 11 Jan Cilliers Street, 7599, Stellenbosch South Africa.

Tel.: +27 (0)21 888 2593; Fax.: +27 (0)21 8882682

E-mail address: sdzikiti@csir.co.za or sdzikiti@gmail.com

\section{Highlights}

- Canopy size rather than crop load was the main driver of water use in apple orchards.

- The Shuttleworth \& Wallace model predicted the water use of young and mature orchards.

- Model simulations were more reliable in mature than in young orchards. 


\section{ABSTRACT}

Exceptionally high yielding (>100 $\mathrm{t} \mathrm{ha}^{-1}$ ) apple orchards (Malus domestica Borkh.) are becoming common in South Africa and elsewhere in the world. However, no accurate quantitative information currently exists on the water requirements of these orchards. Information is also sparse on the water use of young apple orchards. This paucity of data may cause inaccurate irrigation scheduling and water allocation decisions, leading to inefficient use of often limited water resources. The aim of this study was therefore to investigate the dynamics of water use in eight apple orchards in South Africa planted to Golden Delicious and the red cultivars i.e. Cripps' Pink, Cripps' Red and Rosy Glow in order to understand how canopy cover and crop load influence orchard water use. Four of the orchards were young (3-4 years after planting) and non-bearing, while the other four were mature high yielding orchards. Transpiration was monitored using sap flow sensors while orchard evapotranspiration (ET) was measured during selected periods using eddy covariance systems. Scaling up of ET to seasonal water use was done using a modified Shuttleworth and Wallace model that incorporated variable canopy and soil surface resistances. This model provided reasonable estimates in both mature and young orchards. The average yield in the two mature 'Cripps' Pink' was $\sim 110 \mathrm{t} \mathrm{ha}^{-1}$ compared to $\sim 88 \mathrm{t} \mathrm{ha}{ }^{-1}$ in the 'Golden Delicious' orchards. However, average transpiration (Oct-Jun) was $\sim 638 \mathrm{~mm}$ for the 'Cripps' Pink' and $\sim 778 \mathrm{~mm}$ in the 'Golden Delicious' orchards. The peak leaf area index was $\sim 2.6$ and $\sim 3.3$ for the mature 'Cripps' Pink and 'Golden Delicious' orchards. So, canopy cover rather than crop load was the main driver of orchard water use. Transpiration by the young orchards ranged from 130 to $270 \mathrm{~mm}$. The predicted seasonal total ET varied from $\sim 900$ to $1100 \mathrm{~mm}$ in the mature orchards and it was $\sim 500 \mathrm{~mm}$ in the young orchards. Orchard floor evaporation accounted for $~ 18$ to $36 \%$ of ET in mature orchards depending on canopy cover and this increased to more than $60 \%$ in young orchards.

Keywords: Canopy cover; Orchard floor evaporation; Transpiration; Water use model 


\section{INTRODUCTION}

Irrigation is the single most repetitive operation in fruit production, especially in arid and semi-arid regions (Fernandez and Cuevas, 2010; Liu et al., 2014). In key deciduous fruit exporting countries such as Spain, Italy and South Africa, most of the fruit is produced under irrigation (Consoli et al., 2016; Gush and Taylor, 2014). Therefore, the availability of adequate water is critical for the sustainability and growth of the fruit industries (Dzikiti et al., 2017a; Testi et al., 2006). Water resources in these countries are under severe strain from global climate change and increasing competition between different users (Midgley et al., 2014). The average yield of apple (Malus domestica Borkh.) orchards varies considerably between countries. In South Africa, for example, it is approximately $60 \mathrm{t} \mathrm{ha}^{-1}$ (Hortgro, 2016). However, in recent years, exceptionally high yielding orchards that consistently produce more than $100 \mathrm{t} \mathrm{ha}^{-1}$ have become common due to improved plant material and orchard management practices (W. Steyn, pers. comm.). This raises questions on the sustainability of these orchards given the increasingly limited water resources since orchards with high yields of good quality fruit are reported to have higher water requirements (Naor et al., 1997; Naor et al., 2008). While many studies have quantified water use by apple orchards (Gush and Taylor, 2014; Volschenk et al., 2003; Volschenk, 2017), none of them have focused on exceptionally high yielding orchards.

A second important information gap relates to how water use by apple orchards varies from planting until the trees reach the full-bearing age (6-8 yr.). Some studies have quantified evapotranspiration (ET) and its partitioning into tree transpiration and orchard floor evaporation (Gong et al., 2007; Liu et al., 2014). However, these studies only investigated mature orchards and there is no detailed quantitative information on how ET and its components vary from planting until the trees mature. This information is important for irrigation scheduling, designing irrigation systems, water allocation, and developing strategies to cope with droughts, whose frequency and severity is projected to increase e.g. 
in the prime fruit producing Western Cape Province of South Africa (Midgley and Lötze, 2011).

Orchard evapotranspiration is commonly determined using the soil water balance approach (Rallo et al., 2017; Rallo et al., 2014; Volschenk, 2017), micrometeorological techniques such as the eddy covariance (Gush and Taylor, 2014; Dzikiti et al., 2017a), combining microlysimeter derived soil evaporation and transpiration (Bonachela et al., 2001; Testi et al., 2004), and using the surface energy balance method (Cammalleri et al., 2010; Consoli and Papa, 2013; Consoli et al., 2006; Dzikiti et al., 2011). These methods are however, not suited for routine use in orchard water management. Instead, simple crop coefficients $\left(K_{c}\right)$ are widely used to estimate $E T$ from reference evapotranspiration ( $\left.E T_{0}\right)\left(E T=K_{c} \times E T_{0}\right)$, using the guidelines provided in FAO paper number 56 (Allen et al., 1998). Whilst these have proven robust in a number of annual crops, they have been shown to be very site specific for perennial orchard crops where crop coefficients can vary according to variety, rootstock, tree spacing, canopy cover, microclimate and irrigation method (Naor et al. 2008). As a result, published $\mathrm{K}_{\mathrm{c}}$ values can often result in poor estimates of water use for orchard crops. There is therefore a need for more mechanistic models which can provide reliable estimates of ET under a wide range of climatic conditions and management practices which can then be used to derive site specific $\mathrm{K}_{\mathrm{c}}$ values for improved on-farm water resources management. However, in cases where the soil water content falls below threshold values, plants experience water stress and $\mathrm{K}_{\mathrm{c}}$ can be adjusted for the stress according to:

$$
E T=\left(K_{c b} \times K_{s}+K_{e} \times K_{r}\right) E T_{o} \quad\left(\mathrm{~mm} \mathrm{~d}^{-1}\right)
$$

where $K_{c b}$ and $K_{e}$ are the basal and soil evaporation coefficients, $K_{s}$ and $K_{r}$ are the transpiration and evaporation reduction coefficients described in detail by Allen et al. (1998) and Rallo et al. (2017).

According to Bastidas-Obando et al. (2017) and Kool et al. (2014), estimation of ET can be improved by modelling the transpiration and soil evaporation components separately since 
transpiration is disconnected from the soil physical conditions related to soil evaporation. The objectives of this study were to establish the water requirements of apple orchards with varying canopy cover and to quantify how orchard ET is partitioned into transpiration and orchard floor evaporation using the Shuttleworth and Wallace (1985) model. The novelty of this study resides in the fact that, we for the first time, quantify the water requirements of exceptionally high yielding apple orchards that consistently produce in excess of $100 \mathrm{t} \mathrm{ha}^{-1}$ and we document the key drivers of water use in order to inform orchard and water management decisions. Secondly, we provide quantitative information on the water use dynamics of young and mature orchards planted to apple cultivars commonly grown in the Mediterranean climatic regions namely the 'Golden Delicious' and the red varieties. Consoli et al. (2006) conducted a similar study in citrus orchards in Italy. However, there is no accurate information on how apple orchard water use varies from planting until the trees reach full-bearing age which is critical for developing accurate irrigation guidelines. Thirdly, we use this data to evaluate the performance of the modified Shuttleworth and Wallace model in a number of orchards in different climatic regions. The model can potentially be used to improve irrigation decision making e.g. by deriving accurate site-specific crop factors for orchards of different age groups.

\section{MATERIALS AND METHODS}

\subsection{Study sites and plant material}

Data were collected in orchards in two prime apple growing regions in the Western Cape Province of South Africa, namely the Koue Bokkeveld (KBV) plateau region in the 2014/15 season and the Elgin/Grabouw/Vyeboom/Villiersdorp (EGVV) region in the 2015/16 season (Fig. 1). As South Africa is situated in the Southern Hemisphere, the growing season typically starts in September in one year ending in May/June the following year, depending on cultivar. The regions have a Mediterranean-type climate with most of the precipitation 
received in winter (May to August). Consequently, the supply of sufficient water for fruit production is almost entirely dependent upon irrigation over the dry summer growing season. KBV (Fig. 1a) experiences cold winters with the long-term average minimum daily temperatures for the coldest month (July) being $3-4{ }^{\circ} \mathrm{C}$, with occasional snowfalls (Midgley et al., 2014). Summers are generally hot and mean maximum temperatures for the hottest month (February) reach $28-29{ }^{\circ} \mathrm{C}$. Peak summer temperatures exceeding $40{ }^{\circ} \mathrm{C}$ are also common. In contrast, EGVV (Fig. 1b) experiences milder winters and summers as the weather is moderated by proximity to the Atlantic Ocean to the south west (Midgley et al., 2014). Mean minimum daily temperatures in winter are between $8-9{ }^{\circ} \mathrm{C}$ while average maximum summer temperatures are between 25 and $26^{\circ} \mathrm{C}$. Maximum temperatures close to $40^{\circ} \mathrm{C}$ also occur.

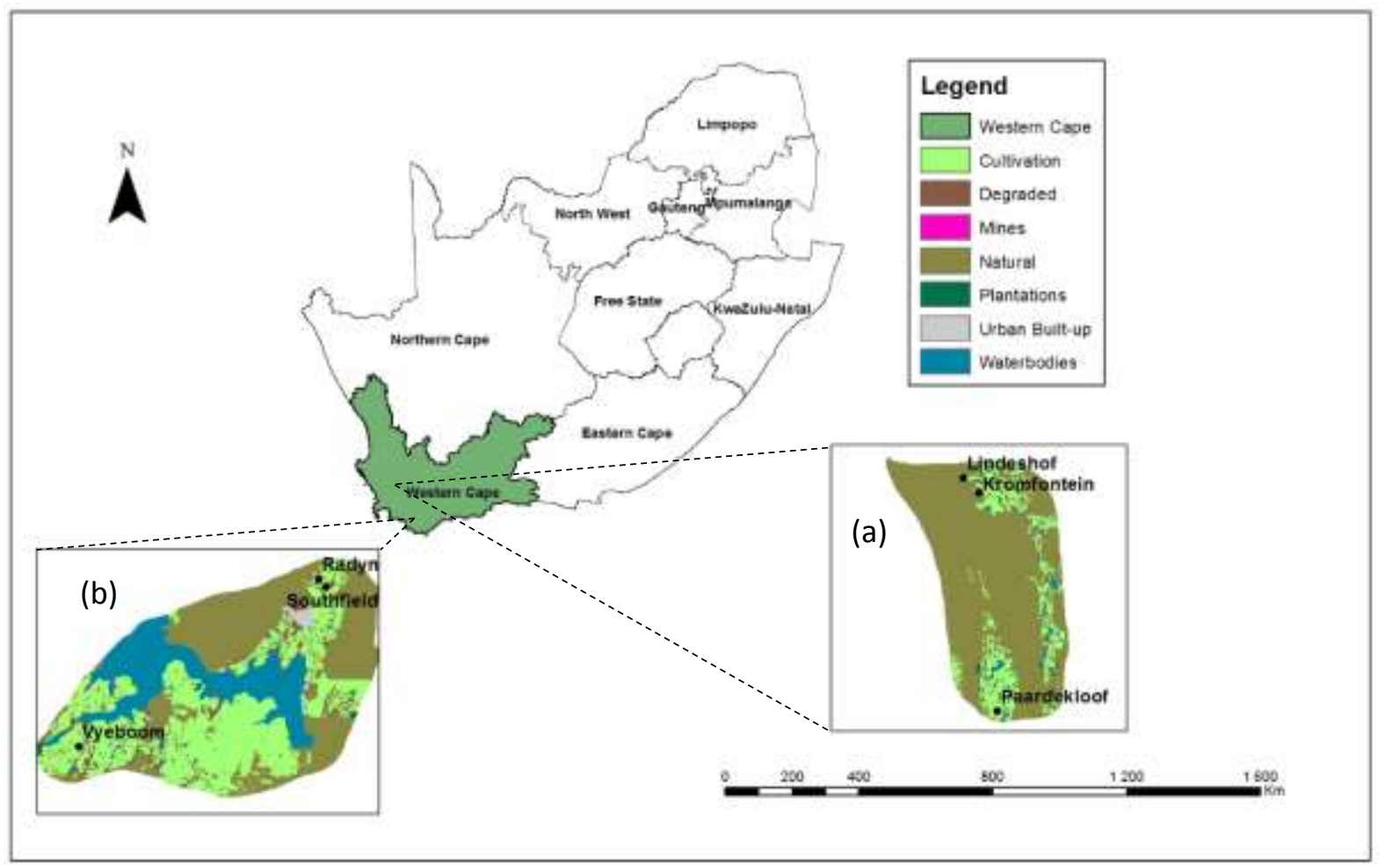

Fig. 1 Map of the two major apple producing regions in the Western Cape Province of South Africa namely the Koue Bokkeveld (KBV, insert a) and the Elgin/Grabouw/Vyeboom/Villiersdorp (EGVV, insert b). 
Cultivars investigated were the Golden Delicious, which is the most widely planted apple cultivar in South Africa occupying approx. $24 \%$ of the area under apples, and the red cultivars i.e. Cripps' Pink/ Cripps' Red/ and Rosy Glow- the latter is a redder strain of Cripps' Pink. All these cultivars are high yielding. The red cultivars were selected as these are late season cultivars. We hypothesized that these cultivars would likely have the highest seasonal water use because they have the longest growing season. The specific red cultivar used depended on the availability of suitable orchards in a particular growing region. In 2014/15, data were collected in two full-bearing orchards planted to 22 year old 'Golden Delicious' (FBGD) and 9 year old 'Cripps' Pink' (FBCP) trees. The orchards were close to each other at Kromfontein farm and each block was about 5.0 ha. Additional data were collected in two non-bearing orchards. One orchard was a 4.0 ha block planted to three year old 'Golden Delicious' (NBGD) trees at Lindeshof farm about $2.5 \mathrm{~km}$ to the north west of Kromfontein (Fig. 1a). The other non-bearing orchard was more than 5.0 ha and planted to four year old 'Rosy Glow' (NBRG) trees at Paardekloof farm, about $30 \mathrm{~km}$ to the south of Kromfontein. Three of the orchards were on M793 rootstock with 1667 trees per hectare (4 $m \times 1.5 \mathrm{~m}$ spacing). Only the NBRG orchard was on the MM109 with a higher plant density of 2285 trees per hectare $(3.5 \mathrm{~m} \times 1.2 \mathrm{~m}$ spacing). Further details of the orchards are presented in Table 1. All full-bearing orchards consistently yielded more than $100 \mathrm{t} \mathrm{ha}^{-1}$ in the two to four years prior to measurements. Soils in all four orchards were predominantly deep sandy soils of the Fernwood soil form (Hyperalbic Arenosol, Soil Classification Working Group, 1991) with a low stone content. The soil hydrological properties, derived from water retention curves in the 150 to $800 \mathrm{~mm}$ depth range in each orchard, are summarized in Table 1.

In the 2015/16 growing season, data were collected in four orchards in EGVV. These comprised a 29 year old 'Golden Delicious' orchard at Southfield farm and a 12 year old 'Cripps' Pink' orchard at Radyn farm, located next to Southfield (Fig. 1b). Both orchards were more than 5 ha and used the rootstock M793. Soils in the FBGD orchard were deep loamy 
Table 1. Attributes of the orchards monitored in KBV during the 2014/15 and in EGVV during the 2015/16 growing season. LAI = leaf area index; FC = volumetric soil water content at field capacity; $\mathrm{WP}=$ volumetric soil water content at the permanent wilting point; $\mathrm{f}_{\mathrm{c}}=$ fractional vegetation cover .

\begin{tabular}{|c|c|c|c|c|c|c|c|c|c|}
\hline \multirow[t]{2}{*}{ Season } & \multirow[t]{2}{*}{ Cultivar } & \multirow[t]{2}{*}{ Orchard age } & \multirow{2}{*}{ ET duration } & \multirow[t]{2}{*}{ Sap flow duration } & \multicolumn{2}{|c|}{ Soil water } & \multirow{2}{*}{$\mathbf{f}_{\mathrm{c}}(-)$} & \multirow{2}{*}{ LAI (-) } & \multirow{2}{*}{ Yield $\left(\mathrm{t} \mathrm{ha}^{-1}\right)$} \\
\hline & & & & & $\mathrm{FC}\left(\mathrm{cm}^{3} / \mathrm{cm}^{3}\right)$ & WP $\left(\mathrm{cm}^{3} / \mathrm{cm}^{3}\right)$ & & & \\
\hline \multirow{4}{*}{$2014 / 15$} & 'Cripps' Pink' & Full-bearing (9 yr.) & $\begin{array}{l}18 \text { to } 28 \text { Sept ' } 14 \\
11 \text { to } 31 \text { Mar '15 } \\
01 \text { to } 15 \text { Apr ' } 15 \\
01 \text { to } 07 \text { Mar ' } 15\end{array}$ & Whole season & 0.174 & 0.049 & 0.43 & 2.6 & 110 \\
\hline & 'Golden Delicious' & Full-bearing (22 yr.) & $\begin{array}{l}07 \text { to } 20 \text { Nov '14 } \\
01 \text { to } 24 \mathrm{Feb} \text { '15 } \\
01 \text { to } 07 \mathrm{Mar} \text { ' } 15 \\
24 \text { to } 27 \mathrm{Apr} \text { ' } 15\end{array}$ & Whole season & 0.171 & 0.047 & 0.52 & 3.2 & 74 \\
\hline & 'Rosy Glow’ & Young (4 yr.) & $\begin{array}{l}17 \text { Sept to10 Oct '14 } \\
16 \text { to } 27 \mathrm{Mar} \text { '15 } \\
02 \text { to } 11 \text { Apr '15 }\end{array}$ & Whole season & 0.193 & 0.042 & 0.10 & 1.3 & - \\
\hline & 'Golden Delicious' & Young (3 yr.) & $\begin{array}{c}16 \text { to } 25 \text { Oct' } 14 \\
07 \text { to } 27 \text { Nov ' } 14 \\
04 \text { to17 Dec '14 } \\
27 \text { Jan to } 27 \text { Feb' } 15\end{array}$ & Whole season & 0.187 & 0.023 & 0.10 & 0.9 & - \\
\hline \multirow{4}{*}{ 2015/16 } & 'Cripps' Pink' & Full-bearing (12 yr.) & $\begin{array}{c}18 \text { to } 23 \text { Oct '15 } \\
04 \text { Nov to } 18 \text { Dec'15 } \\
01 \text { to } 18 \mathrm{Mar}^{\prime} 16 \\
08 \text { to } 16 \text { Apr' } 16 \\
\end{array}$ & Whole season & 0.23 & 0.05 & 0.44 & 2.8 & 109 \\
\hline & 'Golden Delicious' & Full-bearing (29 yr.) & $\begin{array}{l}09 \text { to } 28 \text { Oct ' } 15 \\
18 \text { to } 28 \mathrm{Nov} \text { ' } 15 \\
11 \text { to } 16 \text { Dec '15 }\end{array}$ & Whole season & 0.189 & 0.055 & 0.50 & 3.6 & 102 \\
\hline & 'Cripps' Red' & Young (3 yr.) & $\begin{array}{l}16 \text { to } 31 \text { Dec' } 15 \\
01 \text { to } 16 \text { Jan ' } 16\end{array}$ & Whole season & 0.143 & 0.045 & 0.10 & 0.8 & - \\
\hline & 'Golden Delicious' & Young (4 yr.) & $\begin{array}{l}22 \text { to } 31 \text { Jan '16 } \\
01 \text { to } 18 \text { Feb '16 }\end{array}$ & Whole season & 0.23 & 0.055 & 0.10 & 1.0 & - \\
\hline
\end{tabular}


sand to sandy loams of the Hutton soil form (Cumulic Vertic Endoaquolls, Soil Classification Working Group, 1991) with no stones (<1\%). However, in the FBCP orchard at Radyn, the soils were dark red clayey loam of the Kroonstad soil form (Ochric Planosol) with up to $33 \%$ stone content (Soil Classification Working Group, 1991). Two additional orchards planted to non-bearing trees were monitored at Vyeboom farm, approx. $20 \mathrm{~km}$ to the southwest of the town of Villiersdorp in EGVV (Fig. 1b). These comprised a 6 ha block planted to four year old 'Golden Delicious' trees and a 6.5 ha three year old 'Cripps' Red' (NBCR) orchard with both orchards on the rootstock MM109. Soil type in the 'Golden Delicious' orchard was similar to that in the FBCP, while there were deep sandy loams of the Fernwood soil form (Hyperalbic Arenosol, Soil Classification Working Group, 1991) in the NBCR orchard, with up to $24 \%$ stone content. Tree density was 1250 trees per hectare ( $4 \mathrm{~m} \times 2 \mathrm{~m}$ spacing) for three of the orchards in EGVV except the full-bearing 'Cripps' Pink' which had 1667 trees per hectare (4 $\mathrm{m} \times 1.5 \mathrm{~m}$ spacing).

All the orchards were irrigated using a micro-sprinkler system with one sprinkler per tree. The wetted radius was between 0.80 and1.2 $\mathrm{m}$ in the young orchards and in the FBCP in EGVV. The wetted radius was $\sim 2.0 \mathrm{~m}$ on average in the other three mature orchards. Delivery rate of the sprinklers was $\sim 20 \mathrm{~L} \mathrm{~h}^{-1}$ in the non-bearing 'Rosy Glow' orchard, $\sim 40 \mathrm{~L}$ $\mathrm{h}^{-1}$ in the FBCP in EGVV and in the range $30-35 \mathrm{~L} \mathrm{~h}^{-1}$ in the remaining orchards. The applied irrigation was measured using water flow meters installed on the irrigation lines. In mature orchards, irrigation intervals were approximately once every 2.3 days at the beginning of the season in spring (November), increasing to once every 1.2 days in mid-summer (January). Average irrigation depth ranged from 5.0 to $8.0 \mathrm{~mm} \mathrm{~d}^{-1}$. In the young orchards, irrigation was applied on average once every 4 days at the start of the season in spring and approximately once every 2 days in mid-summer. 


\subsection{Microclimate, sap flow and eddy covariance measurements}

Weather data were recorded using two automatic weather stations located close to the study sites. The stations were installed in open spaces with uniform short grass cover. Weather variables measured included hourly and daily estimates of solar irradiance, air temperature and relative humidity, wind speed and direction and rainfall. Reference evapotranspiration $\left(\mathrm{ET}_{\circ}\right.$ ) was calculated for a short grass using the FAO Penman-Monteith equation (Allen et al. 1998).

Transpiration in full-bearing orchards was measured on six trees of different stem sizes per orchard using the heat ratio method of the heat pulse velocity (HPV) sap flow technique (Burgess et al., 2001). A metal template with three holes spaced $5 \mathrm{~mm}$ apart was used to drill the holes in the stems to minimize probe misalignment. The HPV system comprised heaters implanted into the stems and connected to custom-made relay control modules which controlled the heat application. T-type thermocouple pairs, installed at equal distances $(\sim 0.5 \mathrm{~cm})$ up and downstream of each heater probe measured the sapwood temperature. The thermocouples were connected to multiplexers (Model: AM16/32B Campbell Scientific, Logan UT, USA) which were in turn connected to CR1000 data loggers. Four sets of sensors were installed in the four cardinal directions around the stem on each of the six trees. The sensors were inserted at different depths into the sapwood to account for the radial variation in sap velocity (Wullschleger and King, 2000). The depth of installation of the sensors ranged from 0.7 to $3.5 \mathrm{~cm}$ below the bark depending on stem size. The HPV data was corrected for wounding due to sensor implantation at the end of the experiment according to the approach of Swanson and Whitfield (1981). The conducting sapwood area was determined by injecting a weak solution of methylene blue dye into the stems to determine the extent of the active xylem vessels. Whole-tree transpiration was derived as the sum of the sap flows in four concentric rings in the sapwood with flow in each ring calculated as the product of the sap velocity at each probe depth and the sapwood area represented by that probe as described by Dzikiti et al (2017b). Sap flux density was derived as the ratio of the 
daily sap flow rate of an individual tree to the conducting sapwood area. Orchard level transpiration (in $\mathrm{mm} \mathrm{d}^{-1}$ ) was calculated as the sum of the products of the sap flux density and the stand sapwood area index (i.e. $\mathrm{m}^{2}$ of sapwood per $\mathrm{m}^{2}$ of ground area) for trees in different stem diameter classes.

Transpiration by the smaller trees in the non-bearing orchards was measured using one Granier probe (Model: TDP 10, Dynamax Inc., Houston, USA) (Granier, 1987) per tree. Three trees were instrumented per orchard. The sensors were installed at a height between 50 and $75 \mathrm{~cm}$ from the ground to eliminate errors due to cold sap early in the morning. A double layer of aluminium bubble wrap was wrapped around the sensors to minimize the effects of exogenous heating on the sap temperature signals. Both the TDP and HPV sap flow data was collected at hourly intervals throughout the two growing seasons.

Evapotranspiration (ET) from the orchards was quantified using two open path eddy covariance systems. These comprised sonic anemometers (Model: CSAT3, Campbell Sci. Inc., Utah, USA) which measured the wind speed in 3D. The concentration of atmospheric water vapour and carbon dioxide were measured using infrared gas analysers (IRGA) (Model: LI-7500A, LI-COR Inc., Nebraska, USA). One eddy covariance system was connected to a CR3000 data logger, while the other used a CR5000 data logger, both manufactured by Campbell Scientific. The high frequency data, collected at $10 \mathrm{~Hz}$, was stored on 2 GB memory cards. Additional sensors included a CNR1 net radiometer (Kipp \& Zonen, The Netherlands) on the CR5000 station and a four component CNR 4 net radiometer (Kipp \& Zonen, The Netherlands) on the CR3000 station. Two clusters of soil heat flux plates (Hukseflux, The Netherlands) were installed at $8 \mathrm{~cm}$ depth below the surface to measure the soil heat fluxes under the canopies and between the rows at each station. Soil averaging thermocouples (Model: TCAV, Campbell Sci. Inc., Utah, USA) were installed above the soil heat flux plates at 2 and $6 \mathrm{~cm}$ depths from the surface to correct the measured fluxes for the energy stored by the soil above the plates. The IRGA and sonic anemometers were installed at heights ranging from 1.50 to $1.80 \mathrm{~m}$ above the canopies. 
These heights ensured that the sensors were above the surface roughness sublayer and gave flux footprints of approx. 150 to $180 \mathrm{~m}$ around the tower. Advanced processing of the high frequency eddy covariance data was done using the EddyPro v 6.2.0 software (LI-COR Inc., Nebraska, USA) to correct for fluctuations in air density, lack of sensor levelness etc. Lastly, the eddy covariance data was corrected for lack of energy balance closure using the Bowen ratio method as described by Cammalleri et al (2010).

The volumetric soil water content in the two 'Golden Delicious' orchards in KBV and in the full-bearing 'Golden Delicious' and the 'Cripps' Red' orchards in EGVV were measured using 30 CS616 time domain reflectometers per orchard (Campbell Sci. Inc., Utah, USA). In this study, these sensors sampled the soil water content at four levels in the depth range 150 $800 \mathrm{~mm}$ in the non-bearing orchards, and up to $1100 \mathrm{~mm}$ in the full-bearing orchards in the tree row and at three levels up to $600 \mathrm{~mm}$ in the work row. Between six and eight sensors sampled the water content close to the soil surface $(150 \mathrm{~mm})$ under various wet/dry and sun/shade positions. In the remaining orchards, soil water content was measured close to the soil surface using two to three CS616 probes per orchard.

\subsection{Numerical description of the ET model}

The partitioning of ET into tree transpiration and orchard floor evaporation was modelled using the Shuttleworth and Wallace model. The original equations are given in Shuttleworth and Wallace (1985) and these used a constant stomatal resistance $\left(r_{S T}\right)$ of $400 \mathrm{~s} \mathrm{~m}^{-1}$, while the soil surface resistances $\left(r_{s}^{s_{s}}\right)$ were fixed at 0,500 , and $2000 \mathrm{~s} \mathrm{~m}^{-1}$ for wet, moderately wet, and dry soils, respectively. In this study a variable stomatal conductance $\left(\mathrm{g}_{\mathrm{sT}}=1 / \mathrm{r}_{\mathrm{ST}}\right)$ was employed following Jarvis et al (1976). According to this method, if $g_{s} \max$ is the maximum stomatal conductance for apples, then the stomatal conductance at any given time is moderated by environmental stress factors according to:

$$
g_{S T}=g_{s \max } \times f(R) \times f(T) \times f(V P D) \times f(\theta) \quad\left(\mathrm{m} \mathrm{s}^{-1}\right)
$$


where $f(R), f(T), f(V P D)$ and $f(\theta)$ are the solar radiation $(R)$, air temperature $(T)$, vapour pressure deficit of the air (VPD) and soil water content $(\theta)$ stress factors with values between 0 and 1 . The stress factor expressions took the following forms:

$$
\begin{aligned}
& f(R)=\frac{R}{R+k_{r}} \\
& f(T)=\left(\frac{T-T_{\min }}{T_{o p t}-T_{\min }}\right) \times\left(\frac{T_{\max }-T}{T_{\max }-T_{o p t}}\right)^{\left(\left(T_{\max }-T_{o p t}\right) /\left(T_{o p t}-T\right)\right)} \\
& f(V P D)=e^{-k_{\text {vpd }} * V P D}
\end{aligned}
$$

where $k_{r}, k_{v p d}$ and $\beta$ are parameters obtained by model optimization and are defined in Table 2. Equation 3 has been applied on maple trees (Acer rubrum) by Bauerle et al (2002), while equations 4 and 5 were used in a sugarcane ET model in South Africa by Bastidas-Obando et al (2017). Equation 6 was adopted from Egea et al (2011) where $\theta_{\mathrm{FC}}$ and $\theta_{\mathrm{WP}}$ represent the volumetric soil water content at field capacity and permanent wilting point, respectively in the root zone. Hourly climate, transpiration, ET, soil water content and the leaf area index (LAl: $\mathrm{m}^{2}$ of leaf area per $\mathrm{m}^{2}$ of ground area) data for days when there were complete eddy covariance ET measurements in the FBCP orchard in KBV was used to calibrate the model. There were 34 days spread throughout the growing season that met this criterion. The LAl was measured using a leaf area meter (Model: LI 2000, LI-COR Inc., Nebraska, USA) under diffuse radiation sky conditions, either before sunrise or at sunset. Model optimization was done using the Marquardt iterative method in which parameter values that minimized the 
weighted sum of squared differences between the measured and modelled transpiration and ET were selected.

Table 2. Parameter values for the modified Shuttleworth and Wallace model applied to high yielding and non-bearing apple orchards.

\begin{tabular}{lll}
\hline Parameter & Description & Default value \\
\hline$b_{1}$ & Value of soil surface resistance when $\theta_{15}=\theta_{\mathrm{FC}}\left(\right.$ in s $\left.\mathrm{m}^{-1}\right)$ & 200 \\
$b_{2}$ & Describes the non-linear changes in surface resistance with soil moisture $(-)$ & -5.83 \\
$\beta$ & Describes the curvature of $\mathrm{f}(\theta)(-)$ & 1.231 \\
$k$ & Extinction coefficient & 0.6 \\
$k_{v p d}$ & Describes the influence of the VPD stress factor & 1.33 \\
$k_{r}$ & Describes the curvature of $\mathrm{f}\left(\mathrm{R}_{\mathrm{s}}\right)\left(\right.$ in $\left.\mathrm{W} \mathrm{m}^{-2}\right)$ & 302 \\
$r_{S T}$ & Minimum stomatal resistance for apple trees (in s $\mathrm{m}^{-1}$ ) & 80 \\
$T_{\max }$ & Maximum temperature for complete stomatal closure $\left(\right.$ in $\left.{ }^{\circ} \mathrm{C}\right)$ & 45 \\
$T_{\min }$ & Minimum temperature at which stomata close $\left(\right.$ in $\left.{ }^{\circ} \mathrm{C}\right)$ & 3 \\
$T_{\text {opt }}$ & Optimum temperature for growth of the trees $\left(\right.$ in $\left.{ }^{\circ} \mathrm{C}\right)$ & 23 \\
\hline
\end{tabular}

The soil surface resistance was derived from the soil water content in the top $15 \mathrm{~cm}\left(\theta_{15}\right)$ by fitting a power function proposed for pine forests by Poyatos et al (2007) as:

$$
r_{s}^{s}= \begin{cases}0 & \theta \geq \theta_{F C} \\ b_{1}\left(\frac{\theta_{15}}{\theta_{15 F C}}\right)^{b_{2}} & \theta_{W P}<\theta<\theta_{F C} \\ 2000 & \theta<\theta_{W P}\end{cases}
$$

$b_{1}$ and $b_{2}$ are model parameters obtained by calibrating the soil evaporation sub-model against hourly soil evaporation data measured using eight micro-lysimeters. The microlysimeters were located at different sun/shade and wet/dry positions in the orchard. Soil evaporation measurements were collected in the full-bearing 'Golden Delicious' orchard in KBV from 18 to 20 February 2015 and from 23 to 24 February 2015 in the non-bearing 'Golden Delicious' orchard. The symbol $\theta_{15}$ represents the hourly average soil water content 
of all the soil moisture sensors at the $15 \mathrm{~cm}$ depth, and $\theta_{15 \mathrm{FC}}$ is the volumetric water content at field capacity at the $15 \mathrm{~cm}$ depth.

\subsection{Statistical analysis}

Statistical differences in the sap flux densities of the different cultivars were determined using the Student t-test $(\alpha=0.05)$. The performance of the modified Shuttleworth and Wallace model was evaluated based on the root mean square error (RMSE), mean absolute error (MAE), the slope, intercept and coefficient of determination $\left(R^{2}\right)$. The predictive accuracy of the model was established using the Nash-Sutcliffe Efficiency (NSE) (Nash and Sutcliffe, 1970) computed as:

$$
N S E=1-\left[\frac{\sum_{i=1}^{n}\left(Y_{i}^{o b s}-Y_{i}^{s i m}\right)^{2}}{\sum_{i=1}^{n}\left(Y_{i}^{o b s}-Y^{\text {mean }}\right)^{2}}\right]
$$

where $Y_{i}$ obs is the $i^{\text {th }}$ observation of the daily $\mathrm{ET}, Y_{i}^{\text {sim }}$ is the $i^{\text {th }}$ simulated $\mathrm{ET}$, and $Y^{\text {mean }}$ is the mean ET value and $n$ is the total number of observations. The NSE ranges between $-\infty$ and 1.0 with NSE $=1.0$ being the optimal value and values between 0 and 1.0 are generally viewed as acceptable levels of performance (Moriasi et al., 2007). Values $\leq 0.0$ indicate that the mean observed value is a better predictor than the simulated value which indicates unacceptable model performance.

\section{RESULTS}

\subsection{Climate}

Typical climatic conditions during the $2014 / 15$ season in KBV and $2015 / 16$ in EGVV are summarised in Table 3 . The daily maximum solar radiation for the season in KBV was 28.5 $\mathrm{MJ} \mathrm{m} \mathrm{m}^{-2}$ which was higher than in EGVV, where it peaked at $24.0 \mathrm{MJ} \mathrm{m}^{-2}$, presumably 
Table 3. Monthly summary of the daily mean solar radiation $\left(R_{s}\right)$; maximum ( $\left.T_{\max }\right)$, minimum $\left(T_{\min }\right)$ and average air temperature $\left(T_{\text {avg }}\right)$; maximum $\left(R H_{\max }\right)$ and minimum $\left(\mathrm{RH}_{\mathrm{min}}\right)$ relative humidity; reference evapotranspiration ( $\left.E T_{0}\right)$, and rainfall in the Koue Bokkeveld $(\mathrm{KBV})$ in 2014/15 and in EGVV during 2015/16. KBV and EGVV represent the Koue Bokkeveld and Elgin/Grabouw/Villiersdorp/Vyeboom production regions, respectively.

\begin{tabular}{|c|c|c|c|c|c|c|c|c|c|c|c|c|c|c|c|c|}
\hline & KBV & EGVV & KBV & EGVV & KBV & EGVV & KBV & EGVV & KBV & EGVV & KBV & EGVV & KBV & EGVV & KBV & EGVV \\
\hline Month & $\begin{array}{l}R_{s} \\
\left(M J m^{-2} d^{-1}\right)\end{array}$ & $\begin{array}{l}R_{s} \\
\left(\mathrm{MJ} \mathrm{m}^{-2} \mathrm{~d}^{-1}\right)\end{array}$ & $\begin{array}{l}\mathrm{T}_{\max } \\
\left({ }^{\circ} \mathrm{C}\right)\end{array}$ & $\begin{array}{l}T_{\max } \\
\left({ }^{\circ} \mathrm{C}\right)\end{array}$ & $\begin{array}{l}T_{\min } \\
\left({ }^{\circ} \mathrm{C}\right)\end{array}$ & $\begin{array}{l}T_{\min } \\
\left({ }^{\circ} \mathrm{C}\right)\end{array}$ & $\begin{array}{l}\mathrm{T}_{\text {avg }} \\
\left({ }^{\circ} \mathrm{C}\right)\end{array}$ & $\begin{array}{l}\mathrm{T}_{\text {avg }} \\
\left({ }^{\circ} \mathrm{C}\right)\end{array}$ & $\begin{array}{l}\mathrm{RH}_{\max } \\
\text { (\%) }\end{array}$ & $\begin{array}{l}\mathrm{RH}_{\max } \\
\text { (\%) }\end{array}$ & $\begin{array}{l}\mathrm{RH}_{\text {min }} \\
\text { (\%) }\end{array}$ & $\begin{array}{l}\mathrm{RH}_{\text {min }} \\
\text { (\%) }\end{array}$ & $\begin{array}{l}\text { ETo } \\
(\mathrm{mm})\end{array}$ & $\begin{array}{l}\mathrm{ET}_{\mathrm{o}} \\
(\mathrm{mm})\end{array}$ & $\begin{array}{l}\text { Rain } \\
(\mathrm{mm})\end{array}$ & $\begin{array}{l}\text { Rain } \\
\text { (mm) }\end{array}$ \\
\hline Oct & 21.9 & 19.4 & 30.7 & 36.6 & 2.8 & 6.1 & 17.1 & 17.3 & 96.0 & 99.9 & 11.2 & 15.3 & 150.3 & 118.0 & 2.8 & 20.3 \\
\hline Nov & 24.0 & 22.0 & 31.8 & 36.6 & 4.4 & 6.1 & 17.4 & 17.8 & 95.9 & 93.5 & 13.3 & 5.4 & 154.9 & 143.2 & 43.9 & 31.8 \\
\hline Dec & 28.5 & 24.0 & 33.4 & 39.7 & 7.8 & 8.7 & 20.2 & 21.2 & 95.2 & 94.7 & 12.2 & 11.5 & 201.8 & 169.8 & 0 & 5.1 \\
\hline Jan & 26.9 & 22.2 & 34.6 & 36.6 & 7.7 & 13.4 & 21.7 & 23.1 & 95.9 & 94.3 & 11.1 & 18.0 & 203.2 & 166.4 & 13.5 & 34.5 \\
\hline Feb & 24.9 & 19.8 & 32.7 & 38.0 & 8.9 & 10.3 & 19.3 & 21.2 & 95.4 & 93.3 & 9.3 & 12.9 & 161.0 & 136.9 & 2.5 & 9.1 \\
\hline Mar & 20.5 & 15.0 & 37.3 & 34.1 & 10.1 & 8.1 & 20.3 & 18.9 & 95.9 & 94.2 & 9.3 & 25.0 & 154.0 & 110.3 & 29.5 & 52.1 \\
\hline Apr & 15.7 & 13.0 & 31.7 & 33.5 & 4.4 & 6.2 & 16.4 & 17.0 & 95.1 & 95.8 & 14.7 & 18.6 & 108.7 & 88.6 & 0.25 & 40.4 \\
\hline May & 10.2 & 9.8 & 27.6 & 28.9 & 4.6 & 3.7 & 13.3 & 15.3 & 96.3 & 96.0 & 12.3 & 13.3 & 71.1 & 70.4 & 14.5 & 4.3 \\
\hline Jun & 8.6 & 7.8 & 22.6 & 28.1 & 1.4 & 2.3 & 9.9 & 12.9 & 96.7 & 94.3 & 18.5 & 11.0 & 51.7 & 60.9 & 133.6 & 49.5 \\
\hline Total & & & & & & & & & & & & & 1264.1 & 1064.4 & 280.7 & 247.1 \\
\hline
\end{tabular}


because of the higher incidence of cloud cover in EGVV which is further south and closer to the coast. Average seasonal (October to June) temperature in $\mathrm{KBV}$ was $17.3^{\circ} \mathrm{C}$ with a peak of $37.3^{\circ} \mathrm{C}$ reached in March 2015 and minimum temperature of $1.4{ }^{\circ} \mathrm{C}$ in June 2015 . For EGVV, the mean seasonal temperature was slightly higher than in $\mathrm{KBV}$ being $18.3^{\circ} \mathrm{C}$, with a maximum of $39.7{ }^{\circ} \mathrm{C}$ recorded in December 2015 and a minimum of $2.3^{\circ} \mathrm{C}$ in June 2016 . The seasonal total reference evapotranspiration (ET $)$ was higher in KBV in 2014/15 being 1 $264 \mathrm{~mm}$ compared to $1064 \mathrm{~mm}$ in EGVV in 2015/16. The Koue Bokkeveld received $281 \mathrm{~mm}$ of rainfall in 2014/15 compared to $247 \mathrm{~mm}$ in EGVV and this was approximately $20 \%$ of $\mathrm{ET}_{\text {。 }}$ for both regions. The long-term annual precipitation in KBV is $350-510 \mathrm{~mm}$ while EGVV has higher rainfall $(>510 \mathrm{~mm})$. There was therefore below average rainfall in both production regions for the two seasons.

\subsection{Soil water content and transpiration}

As expected, the soil moisture dynamics at different depths down the soil profile responded to irrigation and rainfall events (Fig. 2). Due to the differences in canopy size, irrigation frequency was generally lower in young (Fig. 2a) compared to mature orchards (Fig. 2b). The mature trees were irrigated more frequently during mid-summer to reduce sunburn damage to the fruit. Water stress occurred on occasion especially in the young orchards as evidenced by the soil water content data in Fig (2a) and in the full-bearing 'Golden Delicious' in KBV (data not shown). In the mature blocks, irrigation was less frequent early in the season when the trees used residual water in the soil from the winter rains and after harvest in early March for the 'Golden Delicious' and April for the 'Cripps' Pink'. 


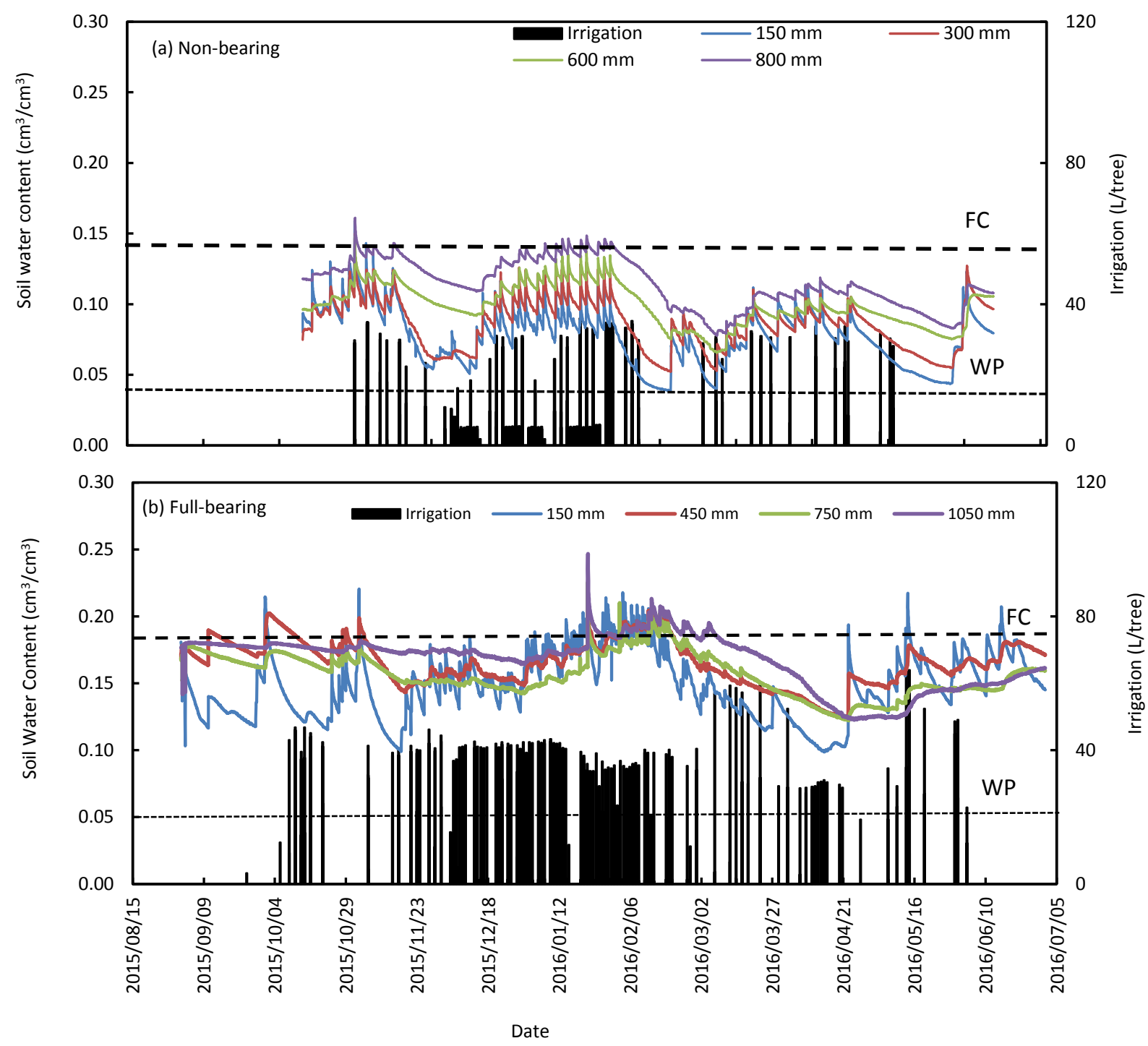

Fig. 2 Dynamics of soil water content at various depths in the root zone of (a) full-bearing 'Golden Delicious', and; (b) non-bearing 'Cripps' Red' apple trees in response to irrigation and rainfall events during the 2015/16 growing season in EGVV.

The sap flux density of both the mature and young orchards closely tracked the atmospheric evaporative demand (Fig. 3a). However, the young trees (Fig 3b) had a higher sap flux density with the peak of $570 \mathrm{~cm}^{3} \mathrm{~cm}^{-2} \mathrm{~d}^{-1}$, almost double that of mature trees (Fig. 3c) which was around $281 \mathrm{~cm}^{3} \mathrm{~cm}^{-2} \mathrm{~d}^{-1}$. In addition, there was no significant difference $(p=0.78)$ in the sap flux density of the Golden Delicious and the red cultivars of the same age group suggesting that the trees had similar water use characteristics. Whole-tree sap flow rates 

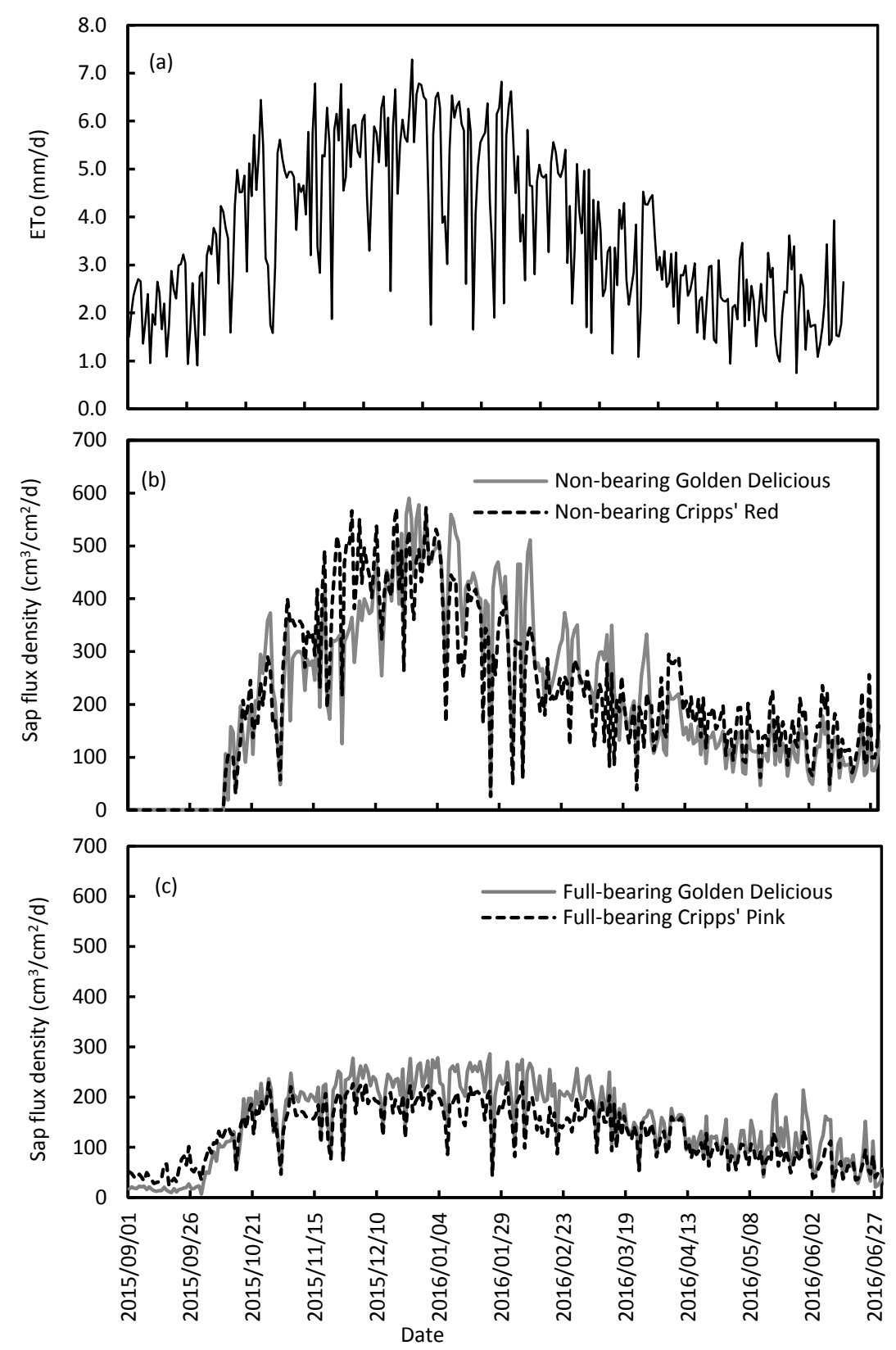

Fig. 3 (a) Seasonal changes in the atmospheric evaporative demand and the sap flux density of; (b) the non-bearing 'Cripps' Pink' and 'Golden Delicious' trees, and; (c) the mature full-bearing trees of the two cultivars. In the EGVV.

were significantly different between the two cultivars for mature trees. Maximum transpiration for the full-bearing 'Golden Delicious' trees was between 35 and $40 \mathrm{~L} \mathrm{~d}^{-1}$ while that for the mature 'Cripps' Pink' trees was between 20 and $25 \mathrm{~L} \mathrm{~d}^{-1}$ in the two production regions. For 
the young trees, maximum transpiration ranged from 8 to $12 \mathrm{~L} \mathrm{~d}^{-1}$ and there were no differences in the rates of water use between the cultivars.

The daily maximum and seasonal total transpiration of the full-bearing 'Golden Delicious' orchards expressed in equivalent depth units, showed no differences between the two production regions. These were 4.8 and $768 \mathrm{~mm}$ in EGVV, and 5.0 and $787 \mathrm{~mm}$ in KBV, respectively. A similar trend was observed in the mature 'Cripps' Pink' orchards. The daily maximum and seasonal transpiration rates were 3.5 and $621 \mathrm{~mm}$ in $\mathrm{KBV}$ compared to 3.9 and $655 \mathrm{~mm}$ in EGVV. Peak LAl for the mature 'Cripps' Pink' $\left(\sim 2.6 \mathrm{~m}^{2} \mathrm{~m}^{-2}\right)$ was lower than that of the 'Golden Delicious' orchards $\left(3.3 \mathrm{~m}^{2} \mathrm{~m}^{-2}\right)$. In the young non-bearing orchards, the maximum daily and seasonal transpiration rates were $1.7 \mathrm{~mm}$ and $199 \mathrm{~mm}$ for the 'Golden Delicious' and 2.0 and $271 \mathrm{~mm}$ for the 'Rosy Glow' in KBV. For the orchards in EGVV, daily maximum and seasonal transpiration were 1.5 and $149 \mathrm{~mm}$ for the 'Golden Delicious' and 1.1 and $127 \mathrm{~mm}$ for the 'Cripps' Red' orchard. The peak mid-season LAI for the non-bearing orchards varied between 0.8 and $1.3 \mathrm{~m}^{2} \mathrm{~m}^{-2}$.

\subsection{Measurement and modelling of evapotranspiration}

The measured daily ET was strongly correlated to the reference evapotranspiration particularly in full-bearing orchards (Fig 4 a \& b) with the coefficient of determination ranging from 0.67 to 0.82 . The $R^{2}$ was much lower in the non-bearing orchards varying from 0.28 to 0.66 (Fig. 4 c \& d). Similarly, the energy balance closure was higher in the mature than in the young orchards. The slope of the graph of the sensible plus latent heat fluxes against the available energy (net radiation minus soil heat flux) ranged from 0.85 to 0.98 in mature orchards compared to between 0.65 and 0.83 in young orchards.

While the ET vs ETo relationships were linear, the slope varied widely across the eight orchards reflecting the seasonal changes in the crop coefficients. Peak daily ET measured in the full-bearing orchards was $9.3 \mathrm{~mm}$ recorded in the 'Golden Delicious' block in EGVV. The highest ET for the non-bearing orchards was $5.1 \mathrm{~mm} \mathrm{~d}^{-1}$ recorded in the 'Golden Delicious' 
block in KBV. An example of how ET for a typical clear day, expressed in equivalent energy units, was partitioned in a full-bearing and a non-bearing 'Golden Delicious' orchard at maximum canopy cover is shown in Fig. 5. Transpiration was the dominant flux in the mature orchard accounting for $78 \%$ of ET. The remainder (22\%) was evaporation from the orchard floor.
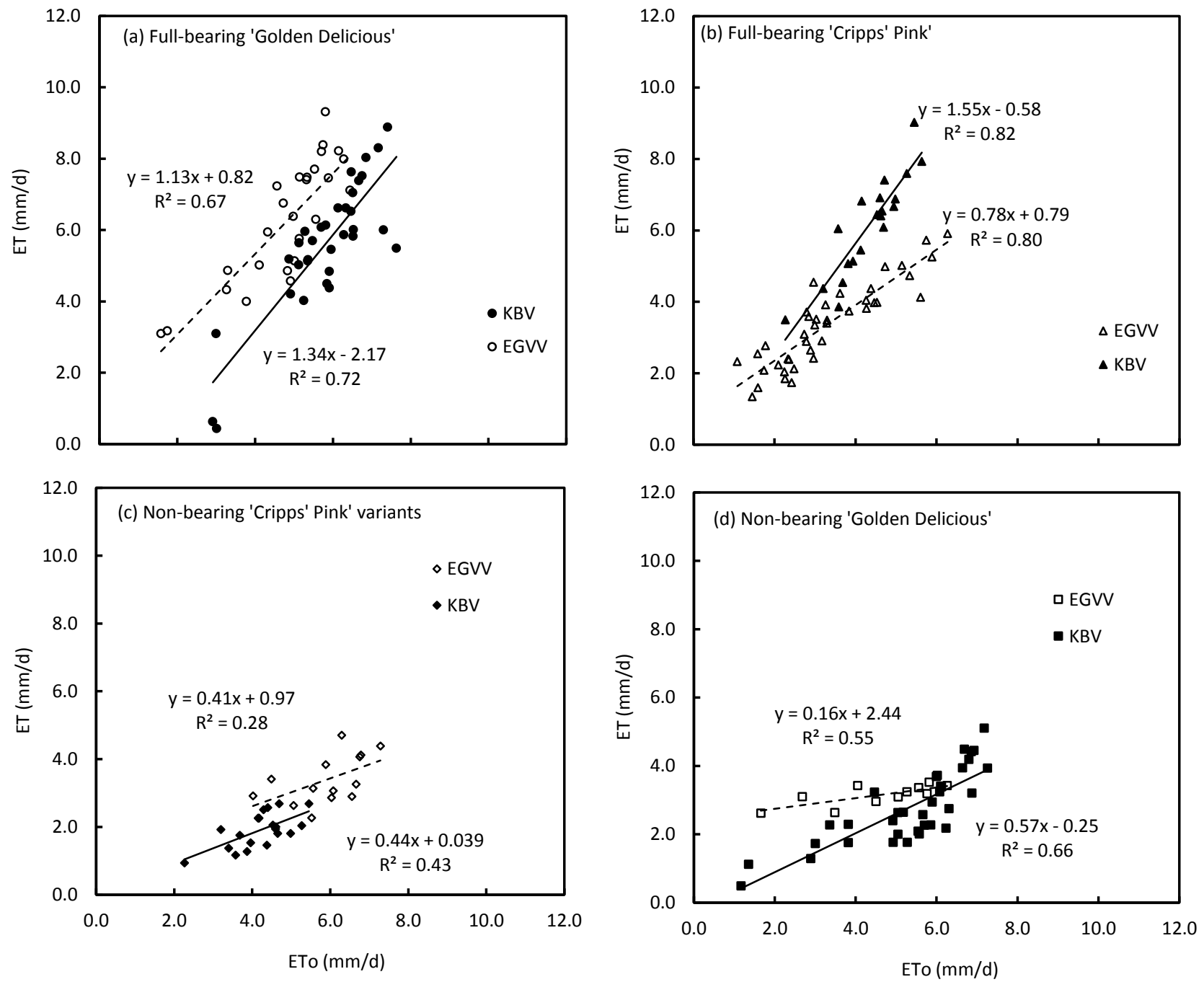

Fig. 4 Effect of the atmospheric evaporative demand (ETo) on the actual evapotranspiration measured in; (a) full-bearing 'Golden Delicious' (FBGD), (b) full-bearing 'Cripps' Pink' (FBCP), (c) non-bearing Rosy Glow (NBRG)/ Cripps' Red (NBCR), and; (d) non-bearing 'Golden Delicious' (NBGD) orchards. 

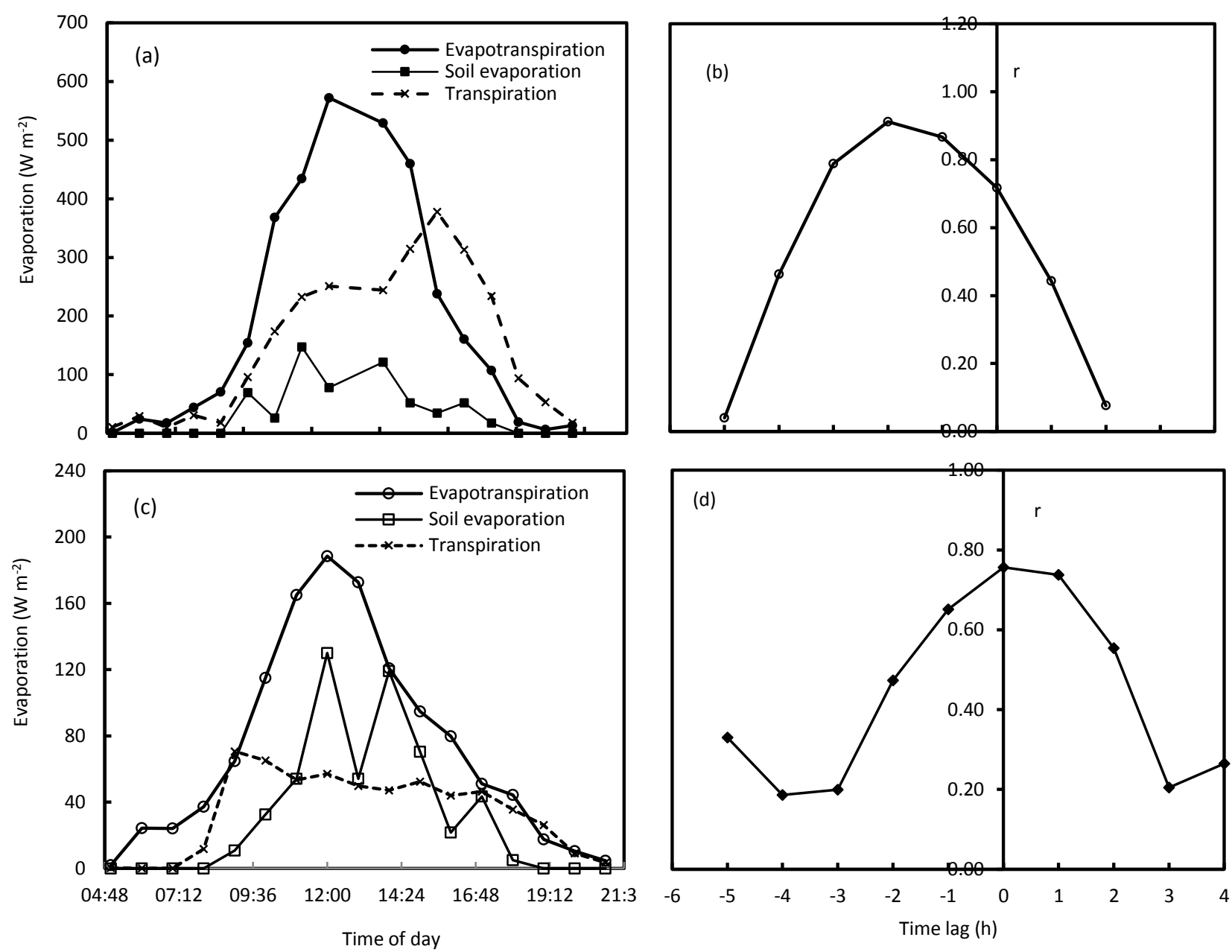

Fig. 5 Partitioning of ET into the transpiration and orchard floor evaporation components in: (a) a fullbearing, and; (b) a non-bearing apple orchard. Typical time lags between the measured ET and transpiration in: (c) a full-bearing, and; (d) a non-bearing apple orchard. The symbol "r" represents the correlation coefficient between ET and T.

The hourly transpiration, derived from the stem sap flow of the mature orchards, was out of phase with the measured ET and Fig. 5a illustrates this for the FBGD for one day. This phase shift could introduce errors in model parameters given the dominance of climate driving variables which are in phase with ET in the Shuttleworth and Wallace model. However, the model does not take into account the capacitance of the trees. By crosscorrelating the ET with transpiration, it is apparent that mature orchard transpiration, as measured on the stems using sap flow sensors, lagged behind ET by up to 2 hours (Fig. 5b), 
and the symbol ' $r$ ' represents the correlation coefficient. The additional novelty of our modelling approach is that we corrected the transpiration data used for model calibration for the time lags to minimize errors due to the mismatch between the climate driving variables and sap flow. In the young orchards, transpiration at full canopy cover accounted for approximately $47 \%$ of ET, with orchard floor evaporation contributing about $53 \%$ to the observed ET (Fig. 5c). There were no time lags between the hourly sap flow derived transpiration and ET in the young orchards, indicating limited capacitance in these small trees (Fig. 5d).

The Shuttleworth and Wallace model accurately predicted the transpiration for the entire season for both mature and young orchards (Fig. 6), albeit with a somewhat larger scatter in non-bearing orchards (Fig. 6b). Table 4 summarises the model performance for predicting transpiration and evapotranspiration in all eight orchards. The Nash-Sutcliffe Efficiency coefficient ranged between 0 and 1.0 for both the transpiration and ET components indicating acceptable model performance. The modelled monthly total ET and its components show that orchard floor evaporation dominated ET at the beginning of the season in September in mature orchards (Fig. 7a). However, the rapid increase in leaf area after bud break resulted in transpiration being almost double the orchard floor evaporation by October and this trend persisted throughout the season. In the young orchards however, orchard floor evaporation was higher than tree transpiration throughout the growing season (Fig. 7b), although our analysis neglects the role of cover crops and weeds that grew on the orchard floor. The predicted seasonal total ET were 1086 and $1110 \mathrm{~mm}$ for the full-bearing 'Golden Delicious' orchards in KBV and EGVV, respectively. Orchard floor evaporation accounted for $\sim 29 \%$ of the ET (Table 5 ) considering the seasonal data. For the mature 'Cripps' Pink' orchards seasonal ET was about $974 \mathrm{~mm}$ in KBV and $902 \mathrm{~mm}$ in EGVV. In these orchards, orchard floor evaporation accounted for up to $36 \%$ of ET, presumably because of the more open canopies of the 'Cripps' Pink' trees, which resulted in a greater proportion of solar radiation reaching the orchard floor. Simulated seasonal ET for the two 
regions was similar for the young 'Golden Delicious' trees being $481 \mathrm{~mm}$ in KBV and 501 $\mathrm{mm}$ in EGVV. For the young 'Rosy Glow' orchard in KBV, the ET total was $562 \mathrm{~mm}$ while the 'Cripps' Red' in EGVV used $500 \mathrm{~mm}$. Orchard floor evaporative losses in the non-bearing orchards accounted for between 52 and $70 \%$ of ET considering the seasonal data.
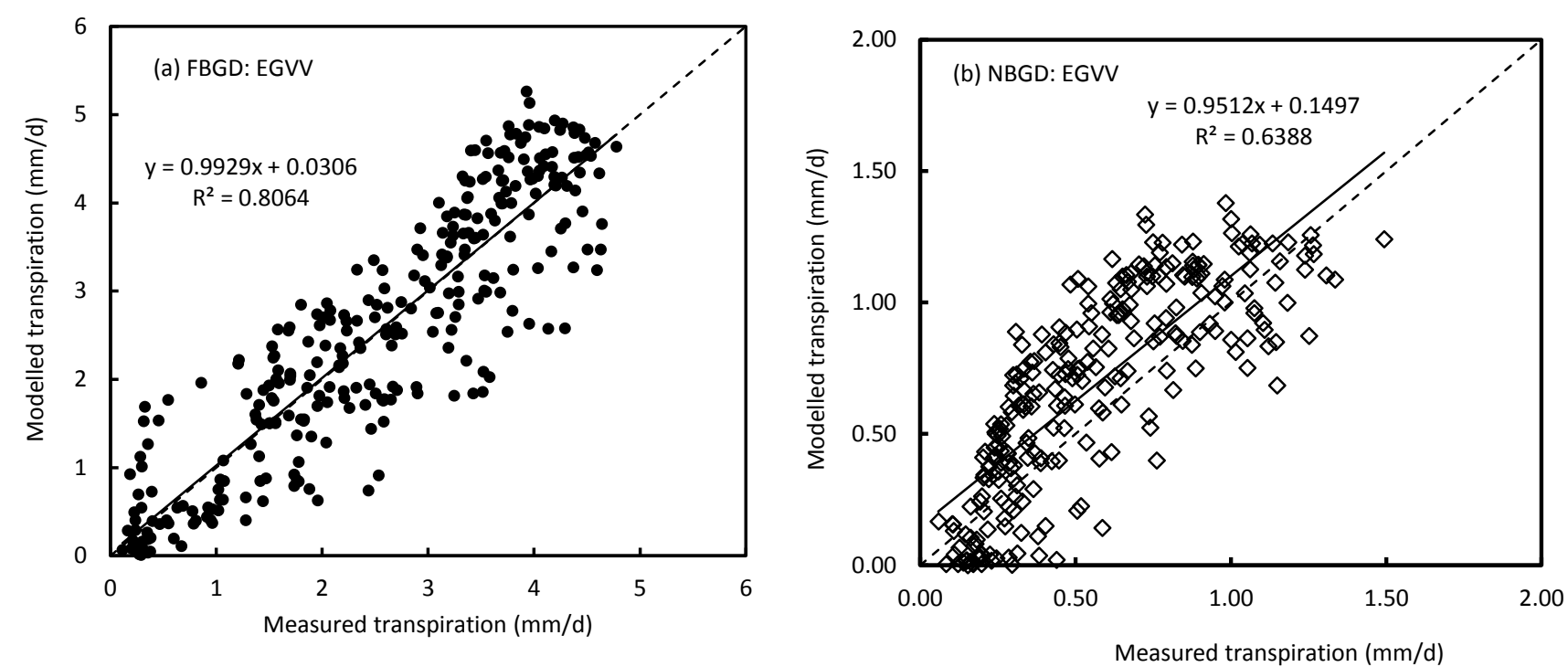

Fig. 6 Comparison of measured and modelled daily transpiration over the entire growing season in:

(a) a full-bearing, and; (b) a non-bearing 'Golden Delicious' apple orchard in EGVV. 
Table 4. Summary statistics for the performance of the Shuttleworth and Wallace model for predicting transpiration (T) and evapotranspiration (ET) at sites in KBV during 2014/15 and in EGVV during the 2015/16 growing season.

\begin{tabular}{|c|c|c|c|c|c|c|c|c|c|}
\hline Region & Orchard & Variable & Slope & Intercept & $\mathbf{R}^{2}$ & RMSE & MAE & NSE & $\mathbf{N}$ \\
\hline \multirow{8}{*}{ KBV } & \multirow[t]{2}{*}{ FBGD } & $T$ & 0.85 & 0.15 & 0.50 & 0.51 & 0.46 & 0.24 & 29 \\
\hline & & ET & 1.02 & 0.54 & 0.73 & 1.10 & 0.94 & 0.21 & 29 \\
\hline & \multirow[t]{2}{*}{ FBCP } & $T$ & 1.07 & 0.07 & 0.91 & 0.42 & 0.33 & 0.85 & 23 \\
\hline & & ET & 0.86 & 0.41 & 0.93 & 0.62 & 0.51 & 0.92 & 23 \\
\hline & \multirow[t]{2}{*}{ NBGD } & $T$ & 0.68 & 0.30 & 0.45 & 0.19 & 0.14 & 0.32 & 43 \\
\hline & & ET & 0.75 & 0.44 & 0.70 & 0.62 & 0.52 & 0.66 & 43 \\
\hline & \multirow[t]{2}{*}{ NBRG } & $T$ & 0.78 & 0.20 & 0.78 & 0.38 & 0.53 & 0.76 & 34 \\
\hline & & ET & 0.87 & 0.31 & 0.60 & 0.42 & 0.60 & 0.47 & 34 \\
\hline \multicolumn{10}{|l|}{$\downarrow$} \\
\hline & \multirow{2}{*}{ FBGD } & $\mathrm{T}$ & 1.11 & 0.15 & 0.76 & 0.59 & 0.51 & 0.42 & 25 \\
\hline & & ET & 0.83 & 0.33 & 0.81 & 0.75 & 0.80 & 0.66 & 25 \\
\hline & FBCP & $T$ & 0.85 & -0.34 & 0.82 & 0.87 & 0.73 & 0.27 & 38 \\
\hline \multirow[t]{5}{*}{ EGVV } & & ET & 1.18 & -0.26 & 0.88 & 0.68 & 0.54 & 0.71 & 38 \\
\hline & \multirow[t]{2}{*}{ NBGD } & $T$ & 0.99 & 0.14 & 0.76 & 0.20 & 0.17 & 0.46 & 12 \\
\hline & & ET & 1.34 & -0.18 & 0.74 & 0.61 & 0.77 & 0.10 & 12 \\
\hline & \multirow[t]{2}{*}{ NBCR } & $\mathrm{T}$ & 0.97 & -0.12 & 0.71 & 0.40 & 0.28 & 0.68 & 14 \\
\hline & & ET & 0.90 & 0.02 & 0.23 & 0.89 & 0.57 & 0.43 & 14 \\
\hline
\end{tabular}



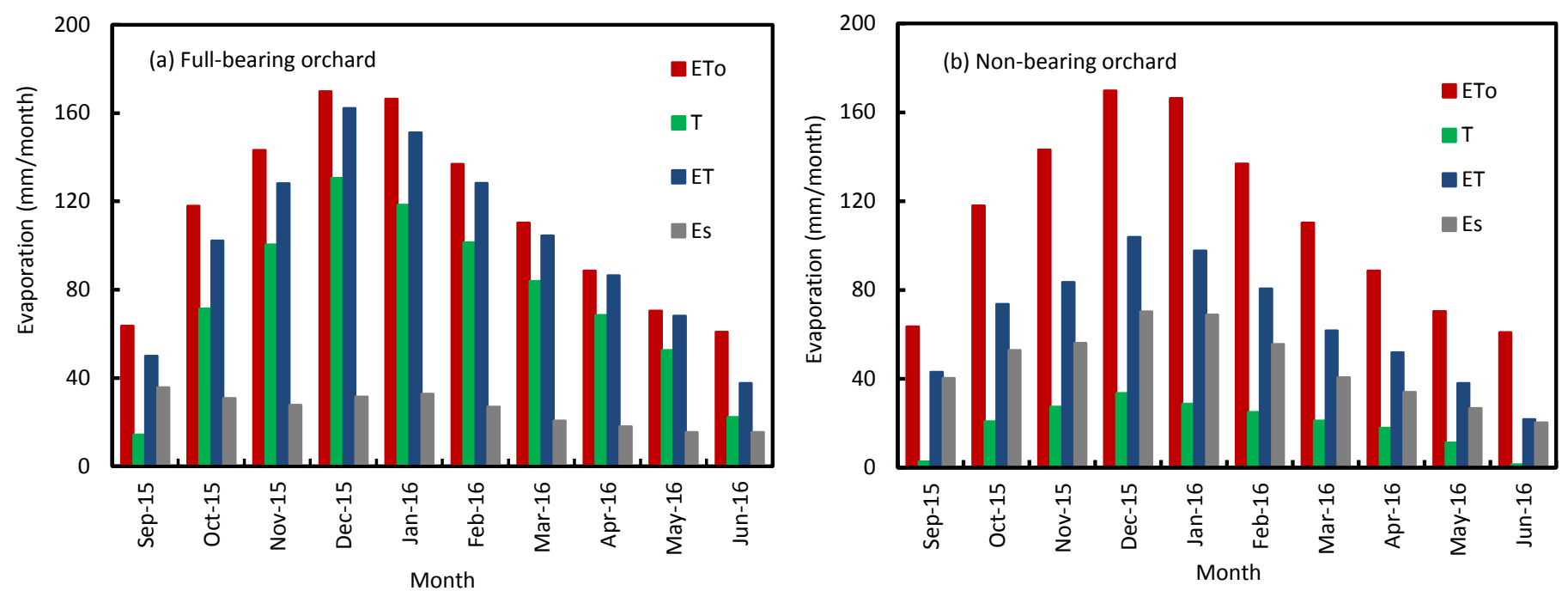

Fig. 7 Simulated monthly total ET and its components namely transpiration (T), and orchard floor evaporation ( $E_{s}$ ) for: (a) full-bearing, and; (b) non-bearing orchards compared with the measured reference evapotranspiration (ETo).

Table 5. Total water use for the 2014/15 growing season in KBV and for the 2015/16 in EGVV. The season starts in September and ends in June the following year. T represents transpiration, $E_{s}$ evaporation from the orchard floor, and ET evapotranspiration.

\begin{tabular}{|c|c|c|c|c|}
\hline \multirow[t]{2}{*}{ Production region } & \multicolumn{4}{|c|}{ Water use (mm/season) } \\
\hline & Orchard & $T$ & $E_{s}$ & ET \\
\hline ? & FBGD & 787 & 299 & 1086 \\
\hline \multirow[t]{4}{*}{ KBV } & $\mathrm{FBCP}$ & 621 & 353 & 974 \\
\hline & NBGD & 199 & 282 & 481 \\
\hline & NBRG & 271 & 291 & 562 \\
\hline & FBGD & 768 & 342 & 1110 \\
\hline \multirow[t]{3}{*}{ EGVV } & FBCP & 655 & 247 & 902 \\
\hline & NBGD & 155 & 346 & 501 \\
\hline & NBCR & 148 & 352 & 500 \\
\hline
\end{tabular}



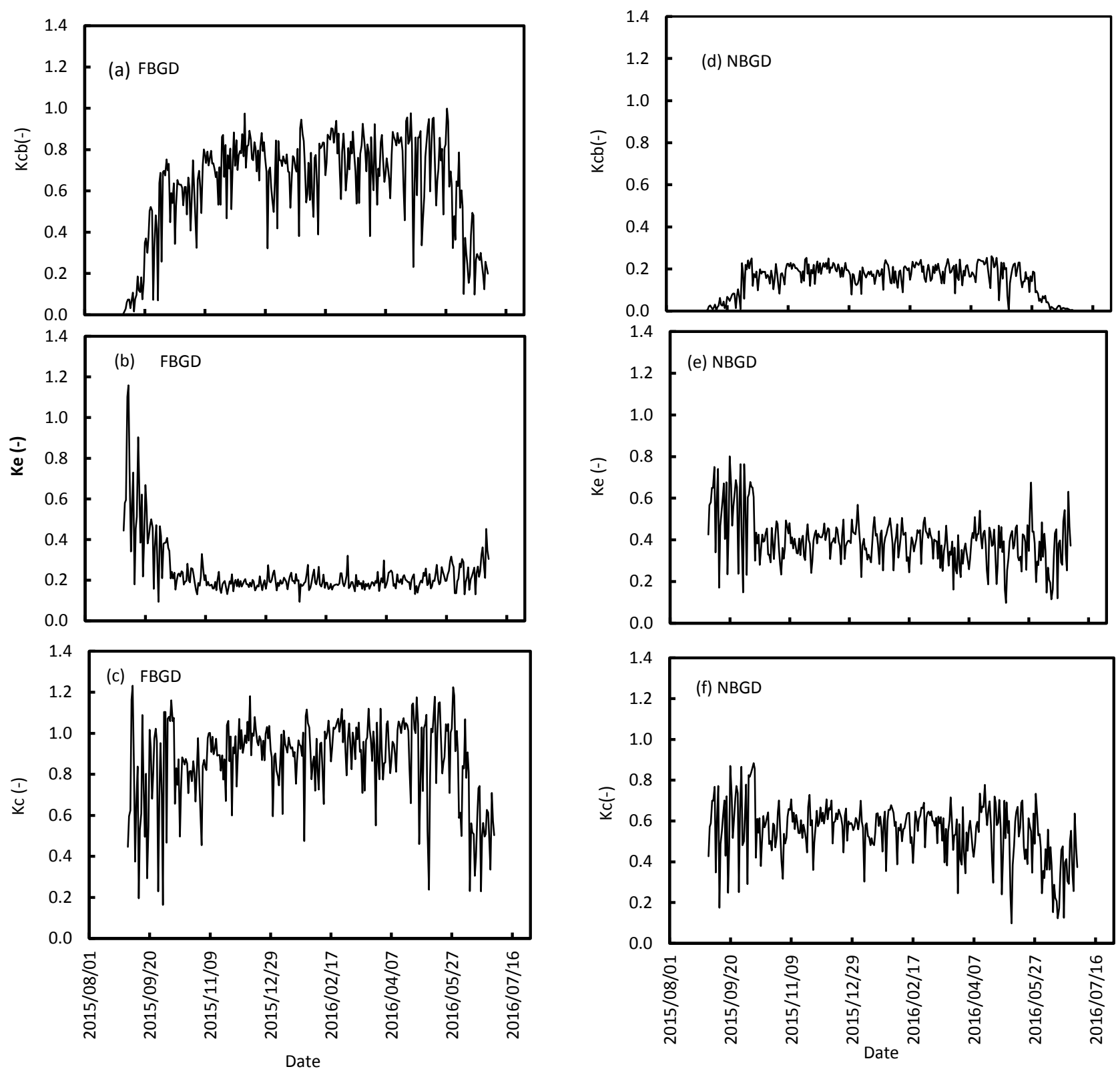

Fig. 8 Seasonal variations in the: (a) basal $\left(\mathrm{K}_{\mathrm{cb}}\right)$, (b) soil evaporation $\left(K_{e}\right)$, and (c) crop coefficients $\left(K_{c}\right)$ for fullbearing apple orchards planted to 'Golden Delicious' and 'Cripps' Pink' trees. Corresponding seasonal variations in the: (d) basal, (e) soil evaporation, and (f) crop coefficients of non-bearing apple orchards.

The mid-season peak basal crop coefficients $\left(\mathrm{K}_{\mathrm{cb}}\right)$, based on actual measured transpiration, were in the range $0.70-0.80$ for mature orchards (Fig. 8a) and approximately 0.20 in non- 
bearing orchards (Fig. 8d). The soil evaporation coefficient $\left(K_{e}\right)$ rapidly dropped from a peak close to 1.0 early in the season stabilizing around 0.2 by mid to late October for mature orchards (Fig. 8b). However, the variability was smaller (0.6-0.4) in the young orchards (Fig 8e) due to the larger proportion of the exposed surface. The mid-season peak crop coefficient $\left(\mathrm{K}_{\mathrm{c}}\right)$ was between 0.95 and 1.10 for the full-bearing orchards (Fig. 8c) and around 0.6 for the young orchards (Fig. 8f).

\section{DISCUSSION}

As expected, mature apple trees used more water than young ones. Seasonal total transpiration exceeded $750 \mathrm{~mm}$ in the full-bearing 'Golden Delicious' orchards in both the KBV and EGVV production regions. However, the sap flux density of the mature 'Golden Delicious' trees was much lower $(\sim 50 \%)$ than that of the young trees of the same cultivar. Similar results were observed on Mangifera Indica L. trees by Oguntunde et al (2011) and in Pinus ponderosa trees by Hubbard et al (1999). The lower sap flux density in older trees can be attributed to a higher hydraulic resistance due to a longer hydraulic path length, and also increased gravitational potential against the ascent of water in the taller trees. Other possible causes of the observed differences in sap flux density include the higher proportion of recent xylem vessels in the young stems compared to the older trees. Sap velocity varies radially across the stem with maximum flow occurring in the newer xylem vessels close to the bark (Delzon et al., 2004; Sevanto et al., 2008; Wulschleger and King, 2000). The sap velocity drops to almost zero towards the heartwood. The fully grown apple trees had considerable heartwood and older xylem vessels with a higher hydraulic resistance (Delzon et al., 2004) likely reducing the mean sap velocity.

However, comparing the effect of cultivar, there were no significant difference in the sap flux density of the 'Golden Delicious' and 'Cripps' Pink'/'Cripps' Red'/'Rosy Glow' trees of a 
particular age group. This is in contrast to observations by Massonnet et al., (2007) who reported substantial differences in the water relations of Braeburn and Fuji apple cultivars on the M9 rootstock. So, it is probable that differences in water use characteristics exist in some apple cultivars but not in others. But further research is needed to confirm this. However, there were significant variations in the seasonal total transpiration of the 'Golden Delicious' and 'Cripps' Pink' trees, especially in mature orchards. These were a result of differences in canopy management practices rather than physiological differences between the two cultivars. For example, growers maintain smaller and more open canopies for 'Cripps' Pink' trees e.g. through shoot thinning and spraying shoot growth retardants such as Regalis ${ }^{\circledR}$. This is done to expose the fruit to solar radiation for anthocyanin synthesis to occur and to promote the development of the red fruit colour. Mature 'Golden Delicious' trees, on the other hand, had larger canopies for shading since the fruit is susceptible to sunburn and there is no need for red colour development. Hence careful canopy management is critical in apple orchards to balance fruit quality and orchard water requirements.

Results from this and other studies also suggest that the effect of exceptionally high crop load on apple orchard water use at the seasonal time scale is quite complex. For example, we observed that the average yields of the full-bearing 'Golden Delicious' orchards were 74 and $102 \mathrm{t} \mathrm{ha}^{-1}$ in KBV and EGVV, respectively. Corresponding seasonal transpiration totals were 768 and $787 \mathrm{~mm}$, respectively. Yield was low in KBV during the study compared to the previous four seasons when the orchard consistently produced more than $100 \mathrm{t} \mathrm{ha}^{-1}$. Since water resources were under pressure, the farm management followed a slightly more aggressive thinning strategy with the aim to conserve water. On the one hand, the yield of the 'Cripps' Pink' was much higher than the 'Golden Delicious' being 110 and $109 \mathrm{t} \mathrm{ha} \mathrm{A}^{-1}$ in KBV and EGVV, respectively. On the other hand, the 'Cripps' Pink' orchards had substantially lower seasonal transpiration totals of 621 and $655 \mathrm{~mm}$ compared to the 'Golden Delicious' orchards. Hence, the 'Cripps' Pink' orchards produced higher yield using less water due to the trees having more open canopies and a higher fruit to leaf ratio. In a 
separate study by Gush and Taylor (2014), also in the KBV region, they measured higher average transpiration over two seasons of $689 \mathrm{~mm}$ in a 13 year old 'Cripps' Pink' orchard which had a much lower average yield of $55 \mathrm{t} \mathrm{ha}^{-1}$. However, these trees had larger canopies (LAI 3.0) than the 'Cripps' Pink' trees studied here. Canopy size therefore appears to be the overriding factor determining seasonal orchard water use, although crop load also has a significant role, at least based on evidence from other studies e.g. Lakatos (2003) and Naschitz and Naor (2005).

The estimated average seasonal total ET for the mature 'Golden Delicious' orchard in the two production regions was around $1068 \mathrm{~mm}$ while the 'Cripps' Pink' used $938 \mathrm{~mm}$. Modelling hourly ET across different orchard age groups is complicated by the differing physiological responses of young and old trees to environmental factors. For example, this study showed that there were significant time lags between the measured hourly orchard ET and transpiration derived from stem sap flow in mature but not in young apple trees. Similar time lags were reported for other species e.g. citrus (Dzikiti et al., 2010), beech and oak trees (Steppe et al., 2006). In addition to the low capacitance, young trees have higher rootto-shoot ratios than older ones (Wolstenholme, 1981). So, it is probable that water supply to the evaporating sites in the leaves is more rapid in these trees, which also have a shorter hydraulic path length leading to shorter time lags between root water uptake and transpiration. In this study we corrected the transpiration data used for model calibration for the time lags leading to a unique set of parameters and better performance of the Shuttleworth and Wallace model at the hourly time step across orchards of different age groups.

The peak crop coefficient $\left(\mathrm{K}_{\mathrm{c}}\right)$ ranged between 0.95 and 1.1 in the mature 'Golden Delicious' orchard and these values are consistent with the observations by Volschenk (2017) also in South African orchards. The contribution of the orchard floor evaporation (non-beneficial water use) to orchard ET was highest in the young than in mature orchards. Kool et al (2014) 
provides a detailed review of the key drivers for ET partitioning and canopy cover, wetted soil fraction, soil water status and the presence of cover crops are likely the main factors in orchards although this was not investigated in this study.

\section{CONCLUSIONS}

This study established that the maximum seasonal water use of the most productive apple orchards in South Africa ranges between 9000 and $11000 \mathrm{~m}^{3} / \mathrm{ha}$. Canopy size (in terms of leaf area) rather than crop load appears to be the main driver of seasonal total transpiration in apple orchards. Therefore canopy management is critical to maintain the balance between fruit quality and overall orchard water use. Despite the fact that 'Cripps' Pink' trees had the longest growing season, this did not translate to higher seasonal water use compared to the shorter season 'Golden Delicious', firstly because of canopy management practices, and secondly because transpiration rates were quite low during the winter months. Adjusting the sap flow derived transpiration rates for time lags in the Shuttleworth and Wallace model improved the model performance in apple orchards with different canopy covers. Lastly, evaporation from the orchard floor was considerably high in the non-bearing orchards because of the small proportion of the shaded orchard floor. Substantial water savings could be achieved by reducing this evaporative component e.g. through using drip irrigation or mulching especially in young orchards, although the beneficial aspects of summer-growing cover crops, e.g. in biological control strategies for insect pests such as mites, need to be considered.

\section{Acknowledgements}

We acknowledge funding from the Water Research Commission of South Africa (Project no WRC K5 2398//4) and the South African Apples and Pears Producers Association. Additional funding from the South African Parliamentary Grant on Water Security (ECHS043) 
is also gratefully acknowledged. We also thank the Du Toit Group, Southfield, Radyn and Vyeboom farms for allowing us to work in their productive orchards. We gratefully acknowledge Mr Louis Reynolds from Fruitful Crop, Mr Daan Brink from Two-A-Day, and Mr Anton Muller from Kromco for assistance with securing the study sites.

\section{References}

Allen RG., Pereira IS., Raes D., Smith M. 1998. Crop evapotranspiration. FAO irrigation and drainage paper 56. Food and Agriculture Organization (FAO), Rome, Italy.

Bauerle W., Post C.J., McLeod M.F., Dudley J.B., Toler J.E. 2002. Measurement and modelling of the transpiration of a temperate red maple container nursery. Agric. For. Meteorol. 114, 45-57.

Bastidas-Obando E., Bastiaanssen W.G.M., Jarmain. C. 2017. Estimation of transpiration fluxes from rain fed and irrigated sugarcane in South Africa using a canopy resistance and crop coefficient model. Agric. Wat. Man. 181, 94-107.

Bonachela S., Orgaz F., Villalobos FJ., Ferres E. 2001. Orchard floor evaporation from drip irrigated olive orchards. Irrig. Sci. 20, 65-71.

Burgess S.S.O., Adams M.A., Turner N.C., Beverly C.R., Ong C.K., Khan A.A.H., Bleby T.M. 2001. An improved heat pulse method to measure low and reverse rates of sap flow in woody plants. Tree Physiol. 21, 589-598.

Cammalleri, C., Agnese, C., Ciraolo, G., Minacapilli, M., Provenzano, G., Rallo, G. 2010 Actual evapotranspiration assessment by means of a coupled energy/hydrologic balance model: Validation over an olive grove by means of scintillometry and measurements of soil water contents. Journal of Hydrology, 392, 70-82. 
Consoli, S., O'Connell, N. V., and Snyder, R. L. (2005). Estimation of evapotranspiration of different sized navel orange-tree orchards using energy balance. J. Irrig. Drain. Eng., 061/(ASCE)0733-9437(2006) 132, 2-8.

Consoli S., Papa R. 2013. Corrected surface energy balance to measure and model the evapotranspiration of irrigated orange orchards in semi-arid Mediterranean conditions. Irrig. Sci. 31, 1159-1171.

Consoli S., Licciardello F., Vanella D., Pasotti L., Villani G., Tomei F. 2016. Testing the water balance model criteria using TDR measurements, micrometeorological data and satellitebased information. Agric. Wat. Man. 170, 68-80.

Delzon S., Sartore M., Granier A., Loustau D. 2004. Radial profiles of sap flow with increasing tree size in maritime pine. Tree. Physiol. 24, 1285-1293.

Dragoni D., Lakso AN., Piccioni RM. 2005. Transpiration of apple trees in a humid climate using heat pulse sap flow gauges calibrated with whole-canopy gas exchange chambers. Agric. For. Meteorol. 130, 85-94

Dzikiti S., Verreynne J.S., Stuckens J., Strever A., Verstraeten W.W., Swennen R., Coppin P. 2010. Determining the water status of Satsuma mandarin trees [Citrus Unshiu Marcovitch] using spectral indices and by combining hyperspectral and physiological data. Agric. For. Meteorol. 150, 369-379.

Dzikiti S., Verreynne J.S., Strever A., Stuckens J., Verstraeten W.W., Swennen R., Theron., K.I., Coppin P. 2011. Seasonal variation in canopy reflectance and its application to determine the water status and water use by citrus orchards in the Western Cape, South Africa. Agric. For. Meteorol. 151, 1035 - 1044.

Dzikiti S., Gush MB., Volschenk T., Taylor NJ., Midgley SJE., Lotze E., Schmeisser M, Doko Q. 2017a. Measurement and modelling of water use in high yielding apple orchards and 
orchards of different age groups in South Africa. Acta Horticulturae. 1150. ISHS 2017. DOI 10.17660/ActaHortic.2017.1150.5

Dzikiti S., Ntshidi Z., Le Maitre DC., Bugan RDH., Mazvimavi D., Schachtschneider K., Jovanovic NZ., Pienaar HH. 2017b. Assessing water use by Prosopis invasions and Vachellia karroo trees: Implications for groundwater recovery following alien plant removal in an arid catchment in South Africa. For. Ecol. Man. 398, 153 -163

Egea G., Verhoef A., Vidale P.L. 2011. Towards an improved and more flexible representation of water stress in coupled photosynthesis-stomatal conductance models. Agric. For. Meteorol. 151, 1370-1384.

Fernández J.E., Cuevas M.V. 2010. Irrigation scheduling from stem diameter 683 variations: a review. Agric. Forest Meteorol. 150, 135-151.

Hubbard, R. M. Bond, B. J. Ryan, M. G. (1999) Evidence that hydraulic conductance limits photosynthesis in old Pinus ponderosa trees," Tree Physiol. 19, 165-172, 1999.

Gong D., Kang S., Yao I., Zhang L. 2007. Estimation of evapotranspiration and its components from an apple orchard in the northwest China using sap flow and water balance. Hydrol. Proc. 21, 931-938.

Granier A.R., 1987. Evaluation of transpiration in a douglas fir stand by means of sap flow measurements. Tree Physiol. 3, 309-320.

Gush M.B., Taylor N.J., 2014. The water use of selected fruit tree orchards (Volume 2): technical report on measurements and modelling. Water Research Commission report no.1770/2/14, WRC, Pretoria, South Africa.

Hortgro., 2016. Key deciduous fruit statistics - 2015, South Africa. www.hortgro.co.za

Jarvis P.G. 1976. The interpretation of the variations in leaf water potential and stomatal conductance found in canopies in the field. Phil. R. Trans. Soc. Lond. B 273, $593-610$. 
Kool D., Agam N., Lazarovitch N., Ben-Gal A. 2014. A review of approaches for evapotranspiration partitioning . Agric. For. Meteorol. 184,56-70.

Lakatos T. 2003. Crop load as a modifying factor in crop evapotranspiration model for irrigation scheduling. Acta Hort. 618, 379-382.

Liu C., Sun G., McNulty S.G., Kang S. 2015. An improved evapotranspiration model for an apple orchard in Northwest China. ASABE. 58, 1253-1264.

Massonnet C., Costes E., Rambal S., Dreyer E., Regnard J.L. 2007. Stomatal Regulation of Photosynthesis in Apple Leaves: Evidence for Different Water-use Strategies between Two Cultivars. Ann. Bot. 100, 1347-1356.

Midgley S.J.E., New M., Methner N., Cole M., Cullis J., Drimie S., Dzama K., Guillot B., Harper J., Jack C., Johnston P., Knowles T., Louw D., Mapiye C., Oosthuizen H., Smit J., van den Broeck, D. 2014. A Status Quo Review of Climate Change and the Agriculture Sector of the Western Cape Province. Report submitted to the Western Cape Department of Agriculture and the Western Cape Department of Environmental Affairs \& Development Planning. African Climate \& Development Initiative, University of Cape Town, Cape Town.

Midgley SJE, Lötze E (2011). Climate change in the Western Cape of South Africa: trends, projections and implications for chill unit accumulation. Acta Hort. 903, 1127-1133.

Monteith J.L., Unsworth M. 1990. Principles of environmental physics. $2^{\text {nd }}$ edition. Antony Rowe Ltd, Eastbourne.

Moriasi DN., J. G. Arnold, M. W. Van Liew, R. L. Bingner, R. D. Harmel, T. L. Veith. 2007. Model evaluation guidelines for systematic quantification of accuracy in watershed simulations. Amer. Soc. Agric. Biol. Engin. 885-900. 
Naor A., Klein I., Doron I., Gal Y., Ben-David Z., Bravdo B. 1997. Irrigation and crop load interactions in relation to apple yield and fruit size distribution. J. Amer. Soc. Hort. Sci. 411 414.

Naor A, Naschitz S, Peres M, Gal Y (2008). Responses of apple fruit size to tree water status and crop load. Tree Physiol. 28, 1255-1261.

Nash, J.E., Sutcliffe, J.V., 1970. River flow forecasting through conceptual modelspart I: a discussion of principles. J. Hydrol. 10, 282-290.

Oguntunde PG., Fasinmirin JT., van de Giesen N (2011). Influence of tree age and variety on allometric characteristics and water use of Mangifera indica L. growing in plantation. J. Botany. doi:10.1155/2011/824201

Poyatos R., Villagarcia L., Domingo F., Pinol J., Llorens P. 2007. Modelling evapotranspiration in a Scots pine stand under Mediterranean mountain climate using the GLUE methodology. Agric. For. Meteorol. 146, 13-28.

Rallo, G., González-Altozano, P., Manzano-Juárez, J., Provenzano, G. 2017. Using field measurements and FAO-56 model to assess the eco-physiological response of citrus orchards under regulated deficit irrigation. Agric. Wat. Man. 180, pp. 136-147.

Rallo, G., Baiamonte, G., Manzano Juárez, J., Provenzano, G. 2014. Improvement of FAO56 model to estimate transpiration fluxes of drought tolerant crops under soil water deficit: Application for olive groves. Journal of Irrigation and Drainage Engineering, 140 (9), art. no. A4014001,

Sevanto S., Nikinmaa E., Riikonen A., Daley M., Pettijohn JC., Mikkelsen TN., Phillips N., Holbrook M. 2008. Linking xylem diameter variations with sap flow measurements. Plant Soil. 305, 77-90.

Shuttleworth WJ., Wallace J. 1985. Evaporation from sparse crops- an energy combination theory. Quart. J. Royal Met. Soc 111, 839-855.

Soil Classification Working Group. 1991. Soil Classification: A taxonomic system for South Africa. Department of Agricultural Development, Pretoria, South Africa. 
Steppe K., Dzikiti S., Lemeur R., Milford J.R. 2006. Stomatal oscillations in orange trees under natural climatic conditions. Ann. Bot. 92, 831 - 835.

Swanson R.H., Whitfield D.W.A. 1981. A numerical analysis of heat pulse velocity theory and practice. J. Exp. Bot. 32, 221-239.

Testi L., Villalobos F.J., Orgaz F., Ferres E. 2006. Water requirements of olive orchards: I daily simulations of evapotranspiration for scenario analysis. Irrig. Sci. 24, 67-76.

Volschenk T., De Villiers J.F., Beukes O. 2003. The selection and calibration of a model for irrigation scheduling of deciduous fruit orchards. Water Research Commission, Pretoria, South Africa. Report no WRC 892.

Volschenk T. 2017. Evapotranspiration and crop coefficients of Golden Delicious/M793 apple trees in the Koue Bokkeveld. Agric. Wat. Man. 194, 184-191.

Wolstenholme, BN.1981. Root, shoot or fruit? South African Avocado Growers' Association Yearbook. 4,27-29

Wullschleger S.D., King A.W.. 2000. Radial variation in sap velocity as a function of stem diameter and sapwood thickness in yellow-poplar trees. Tree Physiol. 20, 511-518 